Analysis of the Effect of Banyuasin District Readiness on the Implementation of Sports Event in South Sumatera Province

\author{
Pelliyezer Karo Karo 1
}

\author{
1 Politeknik Pariwisata Palembang \\ Correspondence : Pelliyezer Karo Karo, Politeknik Pariwisata Palembang \\ Email :pelliyezer@poltekpar-palembang.ac.id \\ DOI : https://doi.org/10.36983/japm.v9i1.73
}

\begin{abstract}
This study was conducted to determine the effect of the readiness of Banyuasin District as a satellite city on the implementation of sports events in South Sumatra Province, where readiness was examined based on eight liveable cities criteria including the physical city, environmental quality, accessibility, facilities, utilities, economy, social and bureaucracy. The data analysis model used is multiple linear regression analysis with the presentation of hypotheses carried out simultaneously and partially. The research sample consisted of 66 domestic and foreign tourists. The results showed that of the eight research variables in Banyuasin Regency simultaneously had a significant effect on the dependent variable in organizing sports events in South Sumatra. Partially, research in Banyuasin District shows that environmental and facility quality variables have a significant effect on the holding of sports events in South Sumatra.
\end{abstract}

Keywords: satellite city, liveable cities, sports event

\title{
Analisis Pengaruh Kesiapan Kabupaten Banyuasin terhadap Penyelenggaraan Sports Event di Provinsi Sumatera Selatan
}

\begin{abstract}
ABSTRAK
Penelitian ini dilakukan untuk mengetahui pengaruh kesiapan Kabupaten Banyuasin sebagai kota satelit terhadap penyelenggaraan sports event di Provinsi Sumatera Selatan, dimana kesiapan diteliti berdasarkan delapan kriteria liveable cities mencakup fisik kota, kualitas lingkungan, aksesbilitas, fasilitas, utilitas, ekonomi, sosial dan birokrasi. Model analisis data merupakan regresi linear berganda dengan penyajian hipotesis dilakukan secara simultan dan parsial. Sample penelitian merupakan para wisatawan domestik dan mancanegara yang berjumlah 66 orang. Hasil penelitian menunjukkan bahwa dari kedelapan variabel penelitian di Kabupaten Banyuasin secara serempak berpengaruh signifikan terhadap variabel terikat penyelenggaraan sports event di Sumatera Selatan. Secara parsial, penelitian di Kabupaten Banyuasin menunjukkan bahwa variabel kualitas lingkungan dan fasilitas berpengaruh signifikan terhadap penyelenggaraan sport event di Sumatera Selatan.
\end{abstract}

Kata kunci: kota satelit, liveable cities, sports event 


\section{PENDAHULUAN}

Sektor pariwisata dipersiapkan menjadi penghasil devisa terbesar di Indonesia pada 2019, diatas sektor migas, minyak kelapa sawit hingga batu bara. Hal tersebut merupakan persiapan untuk menjadikan pariwisata sebagai sektor utama Indonesia. Dari beberapa jenis wisata yang terdapat di Indonesia maka salah satu berpotensi besar dan menjadi perhatian nasional sebagai salah satu proses untuk mencapai tujuan meningkatnya kesejahteraan masyarakat adalah wisata olahraga atau sport event dikarenakan jenis wisata ini melibatkan masyarakat luas dengan berbagai tingkatan dan segmentasi.

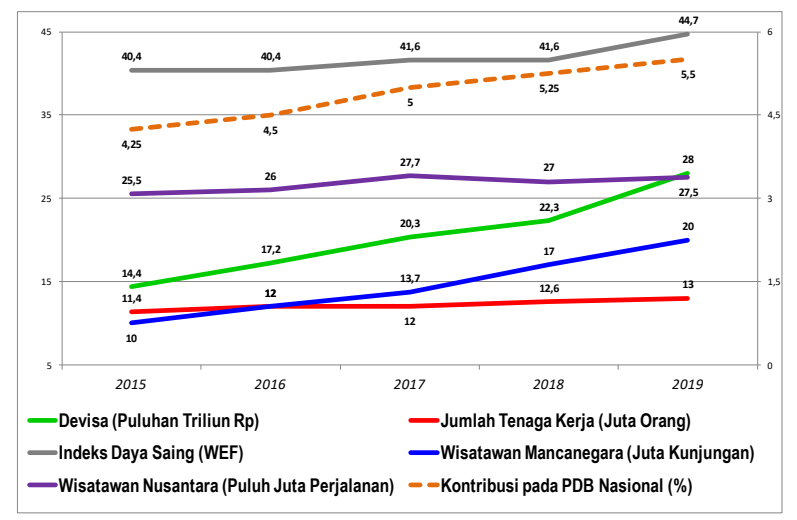

Gambar 1. Grafik Kinerja Sektor

Pariwisata Indonesia

Sumber: BPS dan diolah, 2018 (IBM SPSS Statistics 22)

Salah satu contoh pengaruh sport event bagi kesejahteraan masyarakat adalah Sport Event Tour de Singkarak, dimana pada tahun 2017 memberikan dampak langsung pada ekonomi masyarakat (Direct Impact Economic Tourism) serta media value yang tinggi. Sejak 2013 Amauri Sport Organisation (ASO) merekomendasi Tour de Singkarak menjadi kejuaraan mayor di Asia karena mampu menyedot lebih dari satu juta penonton. setelah penyelenggaraan 9 tahun Tour de Singkarak terjadi pertumbuhan positif di Sumatera Barat seperti petumbuhan hotel dari tahun ke tahun. Pada 2014 tercatat 274 hotel, dan homestay sebanayak 5588 kamar. Di tahun 2016 meningkat menjadi 339 hotel dan homestay sebanyak 7799 kamar.

Pelaksanaan sport event lainnya yakni International Tour de Banyuwangi Ijen dimana Bupati Banyuwangi Abdullah Azwar Anas menyatakan bahwa International Tour de Banyuwangi Ijen bukan semata-mata ajang sport tourism, tetapi satu alat konsolidasi yang merubah budaya masyarakat hingga ke level yang paling bawah. Dampak yang dirasakan dari penyelenggaraan International Tour de Banyuwangi Ijen, dulunya tingkat kedatangan wisatawan pada 2014 hanya 500 ribu orang. Kemudian meningkat di tahun berikutnya menjadi 700 ribu hingga saat pelaksaan pada tahun 2017 sudah mencapai 4,3 juta orang.

Berdasarkan contoh keberhasilan pengelolaan sport event di dua kota tersebut yang melibatkan beberapa kota disekitar kota utama yakni Tour de Singkarak dan Tour de Ijen Banyuwangi yang melalui beberapa Kabupaten / Kota sebagai kota satelit, tentunya membutuhkan ketersiapan masyarakat, sarana, prasarana suatu wilayah dengan standar pelaksanaan International Sport Event. Dengan begitu keberhasilan pelaksanaan sport event harus dapat didukung oleh wilayah aman, nyaman dan memenuhi indikator standar penyelenggaraan sport event.

Dukungan kota satelit yang didefinisikan sebagai kota kecil ditepi sebuah kota besar, meskipun merupakan komunitas mandiri, sebagian besar penduduknya bergantung pada kehidupan di kota besar. Biasanya penghuni kota satelit ini adalah komuter (penunjang) dari kota besar $^{[1]}$. Tentunya perkembangan kota ini sangat diperlukan untuk menunjang keberhasilan pelaksanaan sport event mengingat Provinsi Sumatera Selatan khususnya Kota Palembang sebagai kota utama menjadi tuan rumah pelaksanaan 
Mega Sport Events yakni Asian Games XVIII pada Agustus 2018, memerlukan kesiapan berbagai aspek dari kota satelit disekitar kota Palembang. Dalam penelitian yang merupakan kota penunjang dari Palembang diantaranya adalah Kabupaten Banyuasin.

Kota Palembang, Provinsi Sumatera Selatan menjadi salah satu daerah yang sangat berpotensi untuk menjadi sebuah destinasi sport event berskala nasional maupun internasional. Hal ini berdasarkan adanya Venue Olahraga terbesar di Indonesia yakni Jakabaring Sport City yang merupakan sebuah kompleks olahraga berstandar internasional yang memiliki venue antara lain, Stadion Gelora Sriwijaya, Stadion Lapangan Tenis, Stadion Atletik, Stadion Akuatik, Gedung GOR Ranau (Badminton), Gedung GOR Dempo (Senam), Arena Baseball dan Softball, Shooting Range, Arena Ski Air, Arena Voli Pantai, Arena Panjat Dinding, Arena Sepatu Roda, Arena Petanque, dan Arena Bowling Centre. Sehingga kemudian muncul pertanyaan "Apakah kota satelit dari Palembang yaitu Kabupaten Banyuasin telah sepenuhnya siap mendukung penyelenggaraan sport event di Provinsi Sumatera Selatan?" Hal tersebut menjadi ide dasar dalam melaksanakan penelitian untuk menganalisis pengaruh kesiapan kota satelit dalam penyelenggaraan sport event di Provinsi Sumatera Selatan.

\section{TINJAUAN PUSTAKA}

\section{A. Penelitian Terdahulu}

Rujukan penelitian pertama yaitu penelitian yang dilakukan oleh Ulfi Nurfaedah pada tahun 2015, dengan judul penelitian Analisis Peran Kota Tangerang sebagai Kota Satelit Jakarta pada studi kasus transportasi komuter Tangerang Jakarta. Rujukan penelitian berikutnya berjudul Determinants and Consequences of the Perceived Social Impact of a Sport Event. Penelitian ini ditulis oleh Yuhei
Inoue and Cody T. Havard dari Memphis University pada jurnal Sport of Management pada tahun 2014. Penelitian ini menitikberatkan fokusnya kepada halhal penentu dan konsekuensi dari dampak sosial sport event. Dengan metode survey peneliti berhasil menemukan dampak positif dan negatif dari sebuah sport event.

B. Kota Satelit

Kota satelit merupakan bentuk permukiman kekotaan yang tidak hanya digunakan untuk tidur, tapi juga mampu berkontribusi terhadap pengembangan wilayah dalam bentuk komoditas, jasa dan informasi. Dilihat dari aspek ekonomi dan sosial, kota satelit mempunyai kemampuan yang memadai untuk memenuhi pekerjaan untuk penduduknya dan juga mungkin bagi penduduk di daerah sub-urbanisasi. Sementara itu, sub-urbanisasi hanya berperan sebagai penerima komoditas dan sebagai pemasok tenaga kerja baik ke kota besar maupun ke kota satelit.

Sebuah kota yang layak huni atau Liveable city adalah kota yang berhasil emberikan sebuah kesempatan hidup bagi manusia didalamnya secara layak. Terdapat delapan delapan variabel Liveable cities menurut Symposium IAP 2008. Variabel tersebut merupakan bahan rujukan serta pertimbangan pada penelitian ini dalam menentukan sebuah liveable city, dengan indikator sebagai berikut:

1. Fisik kota mencakup tata ruang, arsitektur, ruang terbuka hijau, ciri dan karakter budaya lokal

2. Kualitas lingkungan mencakup kebersihan kota dan tingkat pencemaran.

3. Transportasi-Aksesibilitas mencakup angkutan umum, kualitas jalan, waktu tempuh ke tempat aktivtas, pedestrian.

4. Fasilitas mencakup fasilitas kesehatan, pendidikan, peribadatan, rekreasi, taman kota.

5. Utilitas mencakup air bersih, listrik,telekomunikasi 
6. Ekonomi mencakup tingkat pendapatan, biaya hidup, ramah investasi

7. Sosial mencakup ruang publik, ruang kreatif, interaksi sosial, kriminalitas, tingkat kesetaraan warga kota, partisipasi warga, dukungan terhadap orang tua, penyandang cacat, dan wanita hamil.

8. Birokrasi mencakup leadership yang kuat, dukungan kebijakan, kepastian hukum, akuntabilitas pemerintah, tingkat penerapan rencana kota, dukungan program pembangunan, dukungan pembiayaan.

\section{Sports event}

Sports event dapat diartikan acara yang diperuntukkan untuk khalayak ramai dengan kegiatan yang melibatkan pengerahan tenaga fisik dan keterampilan di mana individu atau tim bersaing melawan orang lain atau orang lain untuk hiburan dan juga olahraga. Kaplanidou and Vogt $^{[2]}$ menyatakan bahwa sport event adalah sebuah produk pariwisata yang dapat bervariasi ukurannya, artinya Sport Event bisa saja nasional, internasional, Penyelenggaraan event olahraga atau pertandingan olahraga baik yang bersifat multi event atau single event, secara kontinuu dan dalam waktu tertentu telah lama berlangsung di Indonesia, kategori multi event olahraga mencakup Porcanas, Popnas, Pomnas, PON hingga Sea Games sedangkan kategori single event seperti Kejurnas Tae Kwon Do, Kejurnas Bulutangkis hingga ke acara olahraga tingkat kelurahan/kecamatan.

Kennedy (2009) [4] mengatakan bahwa penyelenggara acara mendesain dan mengembangkan acara olahraga yang sukses, dengan tujuan mengumpulkan komunitas di satu lokasi dan melakukan beberapa kegiatan yang telah diatur untuk memperoleh informasi atau menyaksikan suatu peristiwa, sambil mengembangkan suatu kegiatan yang bertujuan untuk menyatukan komunitas / orang di satu lokasi dan melaksanakan beberapa kegiatan yang telah diatur untuk mendapatkan informasi atau melihat suatu peristiwa, atau menargetkan target publik sehingga mereka mengunjungi kegiatan atau acara yang telah dibuat oleh penyelenggara acara. Secara umum, keberhasilan organisasi acara olahraga sebagai berikut: tingkat kehadiran, tingkat antusiasme, nilai emosi acara, dan rangkaian kegiatan.

\section{Kabupaten Banyuasin}

Kabupaten Banyuasin merupakan pemekaran dari Kabupaten Musi Banyuasin Nama kabupaten ini berasal dari nama Sungai Banyuasin. Perkataan banyuasin sendiri berasal dari istilah bahasa Jawa banyu (air) dan asin. Kabupaten Banyuasin memiliki luas wilayah sebesar $11.875 \mathrm{~km}^{2}$ dengan terdiri dari suku menetap antara lain Jawa, Madura, Bugis, Bali dan Melayu.

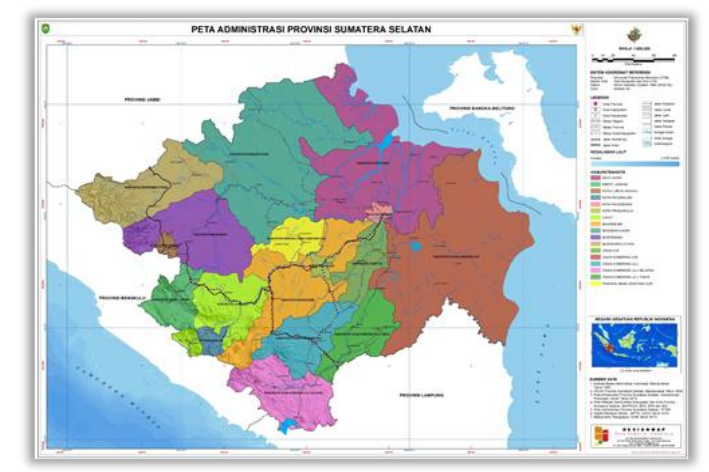

Gambar 2. Peta Administrasi Provinsi Sumatera Selatan

Sumber: petatematikindo.wordpress.com

Batas wilayah Banyuasin hampir sepenuhnya mengelilingi wilayah kota palembang, sehingga Banyuasin dapat dikatakan sebagai wilayah penyangga ibukota provinsi Sumatera Selatan. Pembangunan provinsi Sumatera Selatan dilaksanakan di pinggir wilayah Banyuasin tepat berbatasan wilayah Kota Palembang, seperti sarana kereta api, sekolah, dermaga. Pelaksanaan e-goverment di Banyuasin 
berjalan cukup baik dimana pembangunan infrastruktur TIK telah dibangun sejak 2009 dengan menghubungkan seluruh dinas/badan/kantor dan kecamatan berbasis jaringen fiber optik. Penghargaan yang telah diraih oleh Kabupaten Banyuasin dibidang e-goverment antara lain IOSA juara I Nasional, IDSA 2014, ICT dengan predikat utama, PEGI terbaik se-Sumatera, sehingga Banyuasin dijadikan sebagai tempat studi banding di dalam implementasi e-goverment. Tahun 2017 dari 514 kabupaten/ kota di Indonesia, pelaksanaan e-goverment di Kabupaten Banyuasin terpilih sebagai salah satu daerah cerdas (smart city) oleh Kementerian Komunikasi dan Informasi bekerjasama dengan Kementerian Dalam Negeri.

\section{METODOLOGI}

Penelitian ini dilakukan secara observasional melalui survei bersifat deskriptif analitik. Data hasil survei dikumpulkan dengan teknik wawancara. Berdasarkan data tersebut dilakukan penjabaran penelitian bersifat eksplorasi dengan pendekatan penelitian secara kualitatif menekankan pembangunan naratif atas fenomena dan secara kuantitatif yang ditujukan pada penekanan numerik dari data penelitian yang dihimpun pada lokasi penelitian di Kabupaten Banyuasin Provinsi Sumater Selatan selama bulan Juni hingga Agustus 2018.

\section{Population and Sample}

Populasi pada penelitian ini adalah para wisatawan yang sedang melaksanakan kegiatan wisata di Provinsi Sumatera Selatan pada umumnya dan di lokus Kabupaten Banyuasin khususnya, dimana berdasarkan publikasi data Badan Pusat Statistik (BPS) Provinsi Sumatera Selatan Juli 2018, bahwa pada Mei 2018 wisatawan mancanegara berjumlah 696 orang.
Dengan asumsi 40 persen dari wisatawan melakukan kunjungan atau kegiatan wisata di lokus Kabupaten Banyuasin maka populasi penelitian berjumlah 278 wisatawan. Jumlah sample penelitian ditentukan dengan menggunakan pendekatan Slovin dengan e sebesar 10 persen, diperoleh jumlah sampel dasar dalam penelitian ini adalah sebanyak 73 orang. Metode pengambilan sampel yang digunakan adalah dengan menggunakan nonprobability sampling dengan pendekatan teknik sampling accidental sampling. Akan tetapi, dari seluruh sampel penelitian yang diharapkan, hanya terkumpul 66 wisatawan yang dapat mengisi kuesioner dan dikuantifikasi kemudian.

\section{Pengujian Instrumen}

Pengujian validitas maupun realibilitas dari instrumen penelitian ditujukan kepada 30 orang selain responden sebagai sampel penelitian. Untuk penelitian ini akan dilakukan uji korelasi item total yang juga disebut uji korelasi butir. Uji korelasi item total dilakukan untuk menguji validitas internal setiap item pertanyaan dalam kuesioner. Dalam pengujian ini skor item total dikorelasikan dengan skor total. Untuk melakukan pengujian korelasi butir dapat digunakan rumus pengujian korelasi Product Moment, sehubungan jumlah item pertanyaan untuk penelitian ini relatif kecil maka uji korelasi yang dilakukan adalah uji korelasi item total dikoreksi (corrected item total correlation). Rumus yang digunakan adalah:

$$
r=\frac{r i x(S x)-S i}{\sqrt{\left[(S x)^{2}+(S i)^{2}-2(r i x)(S i)(S x)\right]}}
$$

dimana,

$$
\begin{aligned}
& \text { rix = koefisien korelasi item total } \\
& \mathrm{Si}=\text { standar deviasi skor setiap item } \\
& \text { pertanyaan } \\
& \mathrm{Sx}=\text { standar deviasi skor total }
\end{aligned}
$$


Uji validitas instrumen dalam penelitian dengan cara mengkorelasikan setiap skor item masing-masing variabel dengan skor total variabel tersebut. Hasil perhitungan tersebut kemudian dibandingkan dengan titik kritis $\left(\mathrm{r}_{\text {tabel }}\right)$ pada taraf signifikan 5 persen. Dengan menggunakan degree of freedom $(\mathrm{df})=28$ dan tingkat signifikansi untuk uji dua arah yaitu alpa $(\alpha)$ sebesar 0,05 maka diperoleh nilai $r_{\text {tabel }}$ sebesar 0,361 . Uji validitas instrumen pada Tabel 1 menunjukkan bahwa nilai $r_{\text {hitung }}$ dari setiap butir variabel pertanyaan > nilai $r_{\text {tabel }}$ $(0,361)$, yang artinya setiap butir variabel pertanyaan dinyatakan valid atau layak untuk dijadikan angket penelitian.

\section{Uji Asumsi Klasik}

Model analisis data yang digunakan dalam penelitian ini adalah model regresi. Sebuah model yang baik adalah model dengan kesalahan peramalan yang seminimal mungkin. Oleh karena itu, sebelum model tersebut digunakan seharusnya dapat memenuhi beberapa asumsi yang biasa disebut asumsi klasik, asumsi-asumsi klasik yang harus dipenuhi adalah uji normalitas, uji multikolinearitas dan uji heteroskedastisitas.

Uji normalitas dapat dilakukan dengan uji histrogram, uji nilai $P$ Plot, uji $C h i$ Square, Skewness dan Kurtosis atau uji Kolmogorov Smirnov, untuk mengetahui kenormalan residu dari model regresi.

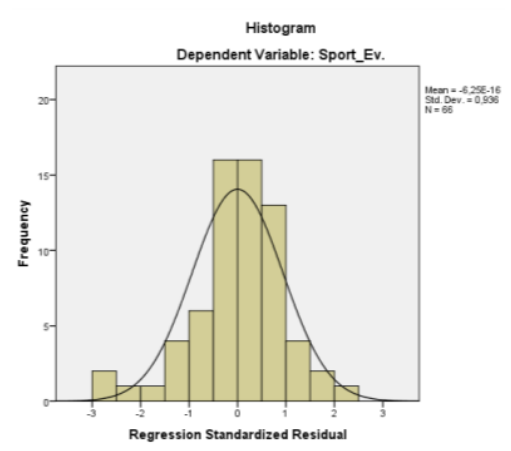

Gambar 3. Grafik Histrogram Uji

Normalitas Kabupaten Banyuasin Sumber: Hasil Penelitian, 2018

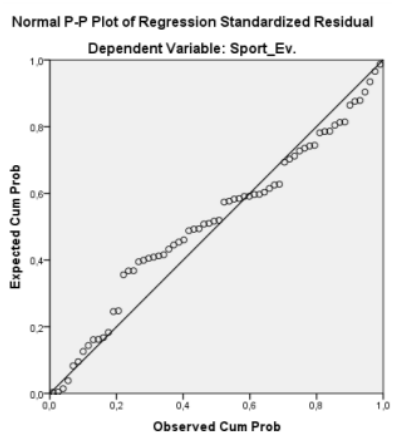

Gambar 4. Grafik Normal Probability Plot Uji Normalitas

Kabupaten Banyuasin

Sumber: Hasil Penelitian, 2018

Berdasarkan Gambar 3 dan Gambar 4 tampilan grafik histogram maupun normal plot, terlihat bahwa setiap titik tersebar disekitar grafik atau garis diagonal dan mengikuti arah grafik ataupun garis diagonal, maka dapat dinyatakan bahwa model regresi memenuhi asumsi normalitas.

Tabel 2. Uji Normalitas menggunakan Kolmogorov Smirnov Test Kabupaten Banyuasin

\begin{tabular}{l|c|c|}
\hline \multicolumn{3}{c}{ Kabupaten Banyuasin } \\
\hline Kolmogorov Smirnov Test & Nilai Hitung & Nilai Tabel \\
\hline Most Extreme Differences (D) & 0,135 & 0,167 \\
\hline Test Statistic (Z) & 0,135 & 0,547 \\
\hline Asymp. Sig. (2 tailed) & $0,005^{\mathrm{a}}$ & 0,109 \\
\hline${ }^{a}$ Lilliefors significance correction & & \\
\hline
\end{tabular}

\section{Sumber: Hasil Penelitian, 2018}

Untuk memperkuat hasil ini, selain analisis grafik, peneliti juga menggunakan uji statistik yaitu uji Kolmogorov Smirnov (K-S) yang ditujukan untuk menguji normalitas residual data. Berdasarkan Tabel 2, dapat dilakukan tiga analisis dari hasil penelitian dengan uji K-S yang diperoleh, antara lain:

1. Most Extreme Differences merupakan nilai statistik $D$ pada $\mathrm{K}$ $\mathrm{S}$ test. Pada Kabupaten Banyuasin, nilai $D_{\text {hitung }}$ absolut diperoleh sebesar 0,135 dibandingkan terhadap nilai 
$\mathrm{D}_{\text {tabel }}$ dengan $\alpha=0,05$ dan $\mathrm{n}=66$ pada tabel statistik Critical Values for Kolmogorov-Smirnov Test diketahui sebesar 0,167. Oleh karena $D_{\text {hitung }}$ lebih kecil dari $\mathrm{D}_{\text {tabel }}$ maka dapat dinyatakan data residual pada Kabupaten Banyuasin berdistribusi normal.

2. Test Statistic Kolmogorov Smirnov pada Kabupaten Banyuasin menunjukkan nilai $Z_{\text {hitung }}$ sebesar 0,135 dibandingkan terhadap nilai $\mathrm{Z}_{\text {tabel }}$ dengan memilih level of significance $\alpha=0,05$ dan dua ujung wilayah kritis (the two-sided critical region) pada tabel distribusi normal standar diketahui sebesar 0,547. Oleh karena $\mathrm{Z}_{\text {hitung }}$ lebih kecil dari $\mathrm{Z}_{\text {tabel }}$ maka dapat dinyatakan data residual pada Kabupaten Banyuasin berdistribusi normal.

3. Asymptotic significance 2 tailed merupakan pengujian nilai probability untuk memastikan bahwa distribusi teramati tidak akan menyimpang secara signifikan dari distribusi yang diharapkan di kedua ujung two tailed distribution. Pada Kabupaten Banyuasin, nilai | F(x)$\mathrm{S}(\mathrm{x}) \mid$ diperoleh sebesar 0,005 dibandingkan terhadap nilai tabel lilliefors dengan $\alpha=0,05$ dan $\mathrm{df}=66$ diketahui sebesar 0,109. Oleh karena nilai $|\mathrm{F}(\mathrm{x})-\mathrm{S}(\mathrm{x})|$ lebih kecil dari nilai tabel lilliefors maka dapat dinyatakan data residual pada Kabupaten Banyuasin berdistribusi normal.

Uji multikolinearitas adalah untuk melihat ada atau tidaknya korelasi yang tinggi antara variabel-variabel independent dalam suatu model regresi linear berganda. Jika ada korelasi yang tinggi diantara variabel-variabel independent tersebut maka hubungan antara variabel independent terhadap variabel dependent menjadi terganggu.
Tabel VIF dan Tolerance Uji

Multikolinearitas Kabupaten Banyuasin

\begin{tabular}{lrrr}
\multirow{2}{*}{\multicolumn{1}{c}{ Variabel }} & \multicolumn{2}{c}{ Kab. Banyuasin } \\
\cline { 2 - 3 } & Tolerance & \multicolumn{1}{c}{ VIF } \\
\hline Fisik Kota &, 801 & 1,248 \\
\hline Kualitas Lingkungan &, 442 & 2,264 \\
\hline Aksesbilitas &, 425 & 2,353 \\
\hline Fasilitas &, 629 & 1,589 \\
\hline Utilitas &, 383 & 2,608 \\
\hline Ekonomi &, 667 & 1,498 \\
\hline Sosial &, 331 & 3,024 \\
\hline Birokrasi &, 514 & 1,945 \\
\hline
\end{tabular}

Sumber: Hasil Penelitian, 2018

Berdasarkan pada Tabel 3. diketahui nilai Tolerance tidak kurang dari 0,10 bermakna tidak ada korelasi antar variabel independent. Hasil perhitungan nilai Variance Inflation Factor (VIF) menunjukkan nilai sama dimana tidak ada satu variabel independent yang memiliki nilai VIF lebih dari 10. Sehingga disimpulkan tidak terjadi multikolonieritas antar variabel independent pada model regresi penelitian dengan lokus Kabupaten Banyuasin.

Uji heteroskedastisitas digunakan untuk menguji model regresi apakah terjadi ketidaksamaan variance residual antar pengamatan. Jika variance residual satu antar pengamatan tetap, maka terjadi homoskedastisitas dan jika berbeda terjadi heteroskedastisitas.

Deteksi heteroskedastisitas dapat dilakukan melalui scatterplot.

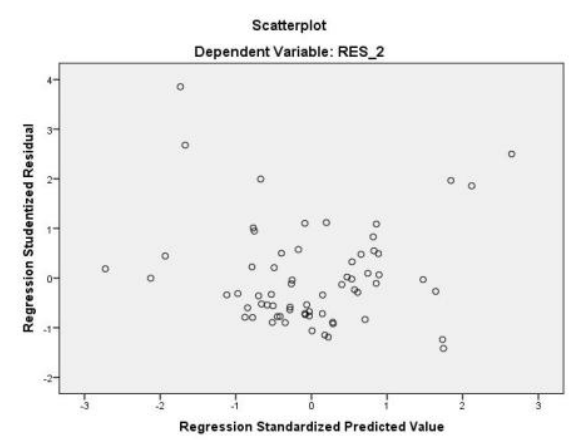

Gambar Grafik Scatterplot Uji

Heteroskedastisitas Kabupaten Banyuasin Sumber: Hasil Penelitian, 2018 
Berdasarkan Gambar 5 menunjukkan bahwa distribusi setiap titik dalam gambar tersebut menyebar dan tidak membentuk suatu pola tertentu seperti bergelombang atau membentuk sebuah garis, bermakna model regresi pada penelitian ini tidak menunjukkan gejala heteroskedastisitas melainkan homoskedastisitas.

Untuk memperkuat hasil uji penelitian, gejala heteroskedastisitas juga diuji dengan menggunakan uji Glejser yaitu dengan meregres nilai absolut residual terhadap variabel independent. Heteroskedastisitas dengan uji Glejser tidak terjadi apabila tidak satupun variabel independent signifikan secara statistik mempengaruhi variabel dependent nilai absolut $\mathrm{Ut}$ (AbsUt).

Tabel Tabel Uji Glejser Uji

Heteroskedastisitas Kabupaten Banyuasin

\begin{tabular}{l|c}
\multicolumn{1}{c}{ Variabel } & Sig. Kab. Banyuasin \\
\hline Fisik Kota &, 817 \\
\hline Kualitas Lingkungan &, 668 \\
\hline Aksesbilitas &, 499 \\
\hline Fasilitas &, 177 \\
\hline Utilitas &, 602 \\
\hline Ekonomi &, 098 \\
\hline Sosial &, 776 \\
\hline Birokrasi &, 385 \\
\hline
\end{tabular}

Sumber: Hasil Penelitian, 2018

Pada Tabel diperoleh tidak ada salah satu dari variabel independent signifikan secara statistik mempengaruhi variabel dependent dari nilai Absolut Ut (AbsUt). Terbukti dari probabilitas signifikansi (Sig.) diatas tingkat kepercayaan 5 persen. Sehingga disimpulkan bahwa model regresi penelitian tidak terjadi heteroskedastisitas.

\section{HASIL DAN PEMBAHASAN}

\section{Analisis Deskriptif}

Analisis deskriptif merupakan suatu kegiatan menyimpulkan data dasar dalam jumlah yang besar sehingga hasilnya dapat ditafsirkan. Pengaturan, pengurutan atau manipulasi data bisa memberikan informasi deskriptif yang akan menjawab pertanyaan-pertanyaan dalam definisi masalah. Pada penelitian ini, responden dibagi menjadi lima karakteristik yaitu berdasarkan usia, jenis kelamin, status perkawinan, pendidikan terakhir dan kategori wisatawan.

Tabel 5. Statistik Deskriptif Responden Kabupaten Banyuasin

\begin{tabular}{|c|c|c|c|c|}
\hline \multirow[b]{2}{*}{ Deskripsi } & \multicolumn{4}{|c|}{ Kab. Banyuasin } \\
\hline & Min. & Max. & Mean & $\begin{array}{c}\text { Std. } \\
\text { Deviati }\end{array}$ \\
\hline Usia & 27 & 56 & 40,30 & 9,009 \\
\hline Jenis Kelamin & 1 & 2 & 1,27 & ,449 \\
\hline Status Perkawinan & 1 & 2 & 1,21 & ,412 \\
\hline Pendidikan Terakhir & 1 & 3 & 2,48 & ,662 \\
\hline Kategori Wst. & 1 & 2 & 1,61 & ,492 \\
\hline
\end{tabular}

Sumber: Hasil Penelitian, 2018

Berdasarkan analisis dari Tabel 5 dapat diperoleh beberapa kesimpulan mendasar dari para responden yaitu:

1. Interval usia responden di Kabupaten Banyuasin berada di 27-56 tahun, dengan rata-rata usia 40 tahun.

2. Responden di Kabupaten Banyuasin didominasi oleh wisatawan pria dan rata-rata responden dari masingmasing lokus sudah menikah.

3. Responden di Kabupaten Banyuasin memiliki pendidikan terakhir lebih mendekati nilai strata sarjana.

4. Responden di Kabupaten Banyuasin dominan merupakan wisatawan mancanegara.

\section{Analisis Regresi Linier Berganda}

Penelitian ini mengkaji seberapa jauh sebuah variabel dependent yaitu dalam hal ini adalah penyelenggaraan sport event yang dipengaruhi oleh beberapa variabel independent yakni dalam penelitian ini delapan variabel liveable cities terdiri dari fisik kota, kualitas lingkungan, aksesbilitas, fasilitas, utilitas, ekonomi, sosial, dan birokrasi maka model analisis yang akan digunakan untuk mengkaji hubungan ini adalah dengan model analisis regresi linier berganda (multiple linear regression). Dalam analisis regresi linier 
berganda akan dikembangkan sebuah persamaan regresi yaitu suatu formula yang mencari nilai variabel dependent dari nilai variabel independent yang diketahui, yaitu:

$$
\begin{aligned}
& \mathrm{Y}=\mathrm{a}+\mathrm{b} 1 \mathrm{X} 1+\mathrm{b} 2 \mathrm{X} 2+\mathrm{b} 3 \mathrm{X} 3+\mathrm{b} 4 \mathrm{X} 4+ \\
& \mathrm{b} 5 \mathrm{X} 5+\mathrm{b} 6 \mathrm{X} 6+\mathrm{b} 7 \mathrm{X} 7+\mathrm{b} 8 \mathrm{X} 8+\mathrm{e} \\
& \text { dimana: }
\end{aligned}
$$

Event

$$
\mathrm{Y}=\text { Penyelenggaraan Sport }
$$

$$
\begin{aligned}
& \mathrm{a}=\text { Konstanta } \\
& \mathrm{X}_{1}=\text { Fisik Kota } \\
& \mathrm{X}_{2}=\text { Kualitas Lingkungan } \\
& \mathrm{X}_{3}=\text { Aksesbilitas } \\
& \mathrm{X}_{4}=\text { Fasilitas } \\
& \mathrm{X}_{5}=\text { Utilitas } \\
& \mathrm{X}_{6}=\text { Ekonomi } \\
& \mathrm{X}_{7}=\text { Sosial } \\
& \mathrm{X}_{8}=\text { Birokrasi } \\
& \mathrm{e}=\text { epsilon atau variabel yang }
\end{aligned}
$$

\begin{tabular}{|c|c|c|c|c|c|c|}
\hline \multicolumn{7}{|c|}{ Coefficients $^{a}$} \\
\hline \multirow[b]{2}{*}{ Mode } & & \multicolumn{2}{|c|}{ Unstandardized Coefficients } & \multirow{2}{*}{$\begin{array}{c}\begin{array}{c}\text { Standardized } \\
\text { Coefficients }\end{array} \\
\text { Beta }\end{array}$} & \multirow[b]{2}{*}{$t$} & \multirow[b]{2}{*}{ Sig. } \\
\hline & & $B$ & Std. Error & & & \\
\hline \multirow[t]{9}{*}{1} & (Constant) & .171 & .619 & & 277 & ,783 \\
\hline & Fisik_Kota &, 007 & .047 & ,008 & 147 & .884 \\
\hline & Kualitas_Lk. & .712 & .071 & .765 & 10,068 & .000 \\
\hline & Aksesbilitas & .056 & .064 & .068 & ,877 & 384 \\
\hline & Fasilitas & 191 & ,059 & ,206 & 3,229 & ,002 \\
\hline & Utilitas & .037 & .057 & .053 & 649 & .519 \\
\hline & Ekonomi & -064 & .050 & -078 & $-1,264$ & ,211 \\
\hline & Sosial &, 020 & .065 & 027 &, 308 & ,759 \\
\hline & Birokrasi &,- 003 & .060 &,- 003 &,- 049 & .961 \\
\hline
\end{tabular}

tidak diteliti

Analisis regresi linier berganda bertujuan untuk mengetahui seberapa besar pengaruh variabel independent menyebabkan terjadinya variabel dependent. Analisis data penelitian dilakukan pada tingkat kepercayaan (confidence of interval) sebesar 95 persen dengan tingkat toleransi kesalahan (alpha) sebesar 5 persen.

Tabel 6. Uji Signifikansi Parameter Individual Kabupaten Banyuasin

Sumber: Hasil Penelitian, 2018

Berdasarkan Tabel dapat diperoleh persamaan regresi linier penelitian yaitu:

$$
\begin{gathered}
Y=0,171+0,007 X_{1}+0,712 X_{2}+0,056 \\
X_{3}+ \\
0,191 X_{4}+0,037 X_{5}-0,064 X_{6}+0,02 X_{7}- \\
0,003 X_{8}
\end{gathered}
$$

Bermakna:

1. Berdasarkan persamaan tersebut, jika $\mathrm{X}_{1}, \mathrm{X}_{2}, \mathrm{X}_{3}, \mathrm{X}_{4}, \mathrm{X}_{5}, \mathrm{X}_{5}, \mathrm{X}_{7}, \mathrm{X}_{8}=0$, maka nilai $Y$ sebesar 1,71. Artinya jika penyelenggaraan sport event tidak dipengaruhi oleh kedelapan variabel fisik kota, kualitas lingkungan, aksesbilitas, fasilitas, utilitas, ekonomi, sosial dan birokrasi di Kabupaten Banyuasin, maka besaran nilai penyelenggaraan sport event adalah 0,171 satuan.

2. Konstanta bernilai 0,171 bermakna rata-rata kontribusi variabel lain diluar model memberikan dampak positif terhadap penyelenggaraan sport event.

3. Persamaan menunjukan jika $X_{1}, X_{2}$, $\mathrm{X}_{3}, \mathrm{X}_{4}, \mathrm{X}_{5}, \mathrm{X}_{5}, \mathrm{X}_{7}, \mathrm{X}_{8}$ ditambah sebesar satu satuan maka penyelenggaraan sport event akan meningkat sebesar $0,007 \mathrm{X}_{1}, 0,712$ $\mathrm{X}_{2}, 0,056 \mathrm{X}_{3}, 0,191 \mathrm{X}_{4}, 0,037 \mathrm{X}_{5}$, $0,064 X_{6}, 0,02 \quad X_{7}$ dan $-0,003 \quad X_{8}$ satuan.

Uji statisik $\mathrm{F}$ digunakan untuk mengidentifikasi variabel independent atau bebas yang dimasukkan dalam model berpengaruh secara bersama terhadap variabel dependent atau terikat. Didalam uji ini juga berarti bahwa semua variabel independent secara simultan merupakan penjelas signifikan terhadap variabel dependent. Uji $\mathrm{F}$ bertujuan untuk mengetahui pengaruh variabel independent secara serempak terhadap variabel dependent dengan tingkat keyakinan 95 persen ( $\alpha=5$ persen).

Untuk menguji pengaruh kesiapan kota satelit berdasarkan teori liveable cities secara serempak terhadap penyelenggaraan 
sport event di Provinsi Sumatera Selatan, digunakan uji Statistik F (uji F). Apabila nilai $F_{\text {hitung }}>$ nilai $F_{\text {tabel, }}$, maka Ho ditolak dan Ha diterima. Sebaliknya apabila nilai $\mathrm{F}_{\text {hitung }}<$ nilai $\mathrm{F}_{\text {tabel, }}$, maka Ho diterima dan Ha ditolak.

Tabel Uji Siginifikansi Simultan Kabupaten Banyuasin

ANOVA $^{\text {a }}$

\begin{tabular}{ll|r|r|r|r|c|}
\hline Model & \multicolumn{1}{c|}{$\begin{array}{c}\text { Sum of } \\
\text { Squares }\end{array}$} & \multicolumn{1}{c|}{ df } & Mean Square & F & Sig. \\
\hline 1 & Regression & 103,916 & 8 & 12,990 & 41,891 &, $000^{\mathrm{b}}$ \\
& Residual & 17,675 & 57 &, 310 & & \\
Total & 121,591 & 65 & & & \\
\hline
\end{tabular}
a. Dependent Variable: Sport_Ev.
b. Predictors: (Constant), Birokrasi, Fasilitas, Utilitas, Fisik_Kota, Ekonomi, Kualitas_Lk.,
Aksesbilitas, Sosial

Sumber: Hasil Penelitian, 2018

Berdasarkan Tabel menunjukkan bahwa lokus Kabupaten Banyuasin memiliki nilai $F_{\text {hitung sebesar 41,891 dan tingkat }}$ signifikansinya sebesar 0,000 sedangkan dengan menggunakan tingkat kepercayaan (confidence interval) 95 persen atau $\alpha=$ $0,05, \mathrm{df} 1=8, \mathrm{df} 2=57$ diperoleh nilai $\mathrm{F}_{\text {tabel }}$ sebesar 2,11. Dengan membandingkan nilai $F_{\text {hitung }}$ dan $F_{\text {tabel }}$, diketahui bahwa $F_{\text {hitung }}(41,891)>F_{\text {tabel }}(2,11)$ dan nilai Sig. $(0,000)<\alpha(0,05)$, bermakna bahwa Ho ditolak, dan $\mathrm{Ha}$ diterima, yang artinya secara serempak variabel liveable cities Kabupaten Banyuasin yang terdiri dari fisik kota, kualitas lingkungan, aksesbilitas, fasilitas, utilitas, ekonomi, sosial dan birokrasi berpengaruh positif dan sangat nyata (high significant) terhadap penyelenggaraan sport event di Provinsi Sumatera Selatan.

Uji statistik $\mathrm{t}$ digunakan untuk mengidentifikasi seberapa jauh pengaruh satu variabel penjelas atau independent secara individual dalam menerangkan variabel terikat atau dependent. Uji t dalam penelitian ini dilakukan untuk menunjukan apakah kedelapan variabel independent fisik kota, kualitas lingkungan, aksesbilitas, fasilitas, utilitas, ekonomi, sosial, dan birokrasi mempunyai pengaruh yang signifikan terhadap variabel dependent penyelenggaraan sport event.

Untuk menguji pengaruh faktor liveable cities yang terdiri dari komitmen, fisik kota, kualitas lingkungan, aksesbilitas, fasilitas, utilitas, ekonomi, sosial dan birokrasi secara parsial terhadap penyelenggaraan sport event di Provinsi Sumatera Selatan, digunakan uji Statistik t (uji t). Apabila nilai $t_{\text {hitung }}>$ nilai $t_{\text {tabel }}$, maka Ho ditolak dan $\mathrm{Ha}$ diterima. Sebaliknya apabila nilai $t_{\text {hitung }}<$ nilai $t_{\text {tabel }}$, maka Ho diterima dan Ha ditolak. Pengujian statsitik $t$ ini dilandaskan pada hasil penelitian Tabel 6 . yang menunjukkan pada lokus Kabupaten Banyuasin, nilai $t_{\text {hitung }}$ setiap variabel independent dibandingkan dengan nilai $t_{\text {tabel }}$ pada confidence interval 95 persen atau $\alpha=0,05 ; \mathrm{df}=64$ dan nilai $\mathrm{t}_{\text {tabel }}$ sebesar 1,998.

Secara parsial uji hipotesis menerangkan bahwa variabel fisik kota $\left(\mathrm{X}_{1}\right)$ memiliki:

1. Nilai $t_{\text {hitung }}$ sebesar 0,147 lebih kecil dari nilai $t_{\text {tabel }}$ yang berarti variabel fisik kota tidak berpengaruh terhadap penyelenggaraan sport event.

2. Nilai signifikansi sebesar 0,884 lebih besar dari nilai $\alpha$ yang berarti variabel fisik kota tidak siginifikan terhadap penyelenggaraan sport event, dimana jika variabel fisik kota bertambah sebesar satu satuan maka penyelenggaraan sport event juga bertambah sebesar 0,007 satuan.

Dengan demikian keputusannya $\mathrm{Ho}_{1}$ diterima dan $\mathrm{Ha}_{1}$ ditolak, bermakna secara parsial variabel fisik kota lokus Kabupaten Banyuasin tidak berpengaruh signifikan terhadap penyelenggaraan sport event di Provinsi Sumatera Selatan.

Secara parsial uji hipotesis menerangkan bahwa variabel kualitas lingkungan $\left(\mathrm{X}_{2}\right)$ memiliki: 
1. Nilai $t_{\text {hitung }}$ sebesar 10,068 lebih besar dari nilai $t_{\text {tabel }}$ yang berarti variabel kualitas lingkungan berpengaruh secara positif terhadap penyelenggaraan sport event.

2. Nilai signifikansi sebesar 0,000 lebih kecil dari nilai $\alpha$ yang berarti variabel kualitas lingkungan berpengaruh signifikan terhadap penyelenggaraan sport event, dimana jika variabel kualitas lingkungan bertambah sebesar satu satuan maka penyelenggaraan sport event juga bertambah sebesar 0,712 satuan.

Dengan demikian keputusannya adalah $\mathrm{Ho}_{2}$ ditolak dan $\mathrm{Ha}_{2}$ diterima, bermakna secara parsial variabel kualitas lingkungan lokus Kabupaten Banyuasin berpengaruh signifikan terhadap penyelenggaraan sport event di Provinsi Sumatera Selatan.

Secara parsial uji hipotesis menerangkan bahwa variabel aksesbilitas $\left(\mathrm{X}_{3}\right)$ memiliki:

1. Nilai $t_{\text {hitung }}$ sebesar 0,877 lebih kecil dari nilai $t_{\text {tabel }}$ yang berarti variabel aksesbilitas tidak berpengaruh terhadap penyelenggaraan sport event.

2. Nilai signifikansi sebesar 0,384 lebih besar dari nilai $\alpha$ yang berarti variabel aksesbilitas tidak siginifikan terhadap penyelenggaraan sport event, dimana jika variabel aksesbilitas bertambah sebesar satu satuan maka penyelenggaraan sport event juga bertambah sebesar 0,056 satuan.

Dengan demikian keputusannya adalah $\mathrm{Ho}_{3}$ diterima dan $\mathrm{Ha}_{3}$ ditolak, bermakna secara parsial variabel aksesbilitas lokus Kabupaten Banyuasin tidak berpengaruh signifikan terhadap penyelenggaraan sport event di Provinsi Sumatera Selatan.

Secara parsial uji hipotesis menerangkan bahwa variabel fasilitas $\left(\mathrm{X}_{4}\right)$ memiliki:

1. Nilai $t_{\text {hitung }}$ sebesar 3,229 lebih besar dari nilai $t_{\text {tabel }}$ yang berarti variabel fasilitas berpengaruh secara positif terhadap penyelenggaraan sport event.

2. Nilai signifikansi sebesar 0,002 lebih kecil dari nilai $\alpha$ yang berarti variabel fasilitas berpengaruh signifikan terhadap penyelenggaraan sport event, dimana jika variabel fasilitas bertambah sebesar satu satuan maka penyelenggaraan sport event juga bertambah sebesar 0,191 satuan.

Dengan demikian keputusannya adalah $\mathrm{Ho}_{4}$ ditolak dan $\mathrm{Ha}_{4}$ diterima, bermakna secara parsial variabel fasilitas lokus Kabupaten Banyuasin berpengaruh signifikan terhadap penyelenggaraan sport event di Provinsi Sumatera Selatan.

Secara parsial uji hipotesis menerangkan bahwa variabel utilitas $\left(\mathrm{X}_{5}\right)$ memiliki:

1. Nilai $t_{\text {hitung }}$ sebesar 0,649 lebih kecil dari nilai $t_{\text {tabel }}$ yang berarti variabel utilitas tidak berpengaruh terhadap penyelenggaraan sport event.

2. Nilai signifikansi sebesar 0,519 lebih besar dari nilai $\alpha$ yang berarti variabel utilitas tidak siginifikan terhadap penyelenggaraan sport event, dimana jika variabel utilitas bertambah sebesar satu satuan maka penyelenggaraan sport event juga bertambah sebesar 0,037 satuan.

Dengan demikian keputusannya adalah $\mathrm{Ho}_{5}$ diterima dan $\mathrm{Ha}_{5}$ ditolak, bermakna secara parsial variabel utilitas lokus Kabupaten Banyuasin tidak berpengaruh signifikan terhadap penyelenggaraan sport event di Provinsi Sumatera Selatan.

Secara parsial uji hipotesis menerangkan bahwa variabel ekonomi $\left(\mathrm{X}_{6}\right)$ memiliki:

1. Nilai $t_{\text {hitung }}$ sebesar $-1,264$ lebih kecil dari nilai $t_{\text {tabel }}$ yang berarti variabel ekonomi tidak berpengaruh terhadap penyelenggaraan sport event.

2. Nilai signifikansi sebesar 0,211 lebih besar dari nilai $\alpha$ yang berarti 
variabel ekonomi tidak siginifikan terhadap penyelenggaraan sport event, dimana jika variabel ekonomi bertamnbah sebesar satu satuan maka penyelenggaraan sport event juga bertambah sebesar -0,064 satuan.

Dengan demikian keputusannya adalah $\mathrm{Ho}_{6}$ diterima dan $\mathrm{Ha}_{6}$ ditolak, bermakna secara parsial variabel ekonomi lokus Kabupaten Banyuasin tidak berpengaruh signifikan terhadap penyelenggaraan sport event di Provinsi Sumatera Selatan.

Secara parsial uji hipotesis menerangkan bahwa variabel sosial $\left(\mathrm{X}_{7}\right)$ memiliki:

1. Nilai $t_{\text {hitung }}$ sebesar 0,308 lebih kecil dari nilai $t_{\text {tabel }}$ yang berarti variabel sosial tidak berpengaruh terhadap penyelenggaraan sport event.

2. Nilai signifikansi sebesar 0,759 lebih besar dari nilai $\alpha$ yang berarti variabel sosial tidak siginifikan terhadap penyelenggaraan sport event, dimana jika variabel sosial bertambah sebesar satu satuan maka penyelenggaraan sport event juga bertambah sebesar 0,02 satuan.

Dengan demikian keputusannya adalah $\mathrm{Ho}_{7}$ diterima dan $\mathrm{Ha}_{7}$ ditolak, bermakna secara parsial variabel sosial lokus Kabupaten Banyuasin tidak berpengaruh signifikan terhadap penyelenggaraan sport event di Provinsi Sumatera Selatan.

Secara parsial uji hipotesis menerangkan bahwa variabel birokrasi $\left(\mathrm{X}_{8}\right)$ memiliki:

1. Nilai $t_{\text {hitung }}$ sebesar $-0,049$ lebih kecil dari nilai $t_{\text {tabel }}$ yang berarti variabel birokrasi tidak berpengaruh terhadap penyelenggaraan sport event.

2. Nilai signifikansi sebesar 0,961 lebih besar dari nilai $\alpha$ yang berarti variabel birokrasi tidak siginifikan terhadap penyelenggaraan sport event, dimana jika variabel birokrasi bertambah sebesar satu satuan maka penyelenggaraan sport event juga bertambah sebesar $-0,003$ satuan.
Dengan demikian keputusannya adalah $\mathrm{Ho}_{8}$ diterima dan $\mathrm{Ha}_{8}$ ditolak, bermakna secara parsial variabel birokrasi lokus Kabupaten Banyuasin tidak berpengaruh signifikan terhadap penyelenggaraan sport event di Provinsi Sumatera Selatan.

Koefisien determinasi digunakan untuk mengukur kemampuan pengaruh variabel independent terhadap variabel dependent, dengan mempertimbangkan kondisi dimana ketika besaran derajat bebas menurun akan berkaitan dengan bertambahnya variabel bebas atau variabel penjelas di dalam regresi, juga dihitung $\mathrm{R}^{2}$ yang disesuaikan dengan adjusted $\mathrm{R}^{2}$ sebagai berikut:

$$
\text { Adjusted } R^{2}=1-1\left(1-R^{2}\right)\left[\frac{n-1}{n-k}\right]
$$

Dimana:

$\mathrm{n}=$ jumlah observasi atau sampel data

$\mathrm{k}=$ jumlah parameter atau koefisien yang diestimsi.

Tabel 8. Uji Koefisien Determinasi Kabupaten Banyuasin

Model Summary

\begin{tabular}{|l|l|r|r|r|}
\hline Model & $\mathrm{R}$ & R Square & $\begin{array}{c}\text { Adjusted R } \\
\text { Square }\end{array}$ & $\begin{array}{c}\text { Std. Error of } \\
\text { the Estimate }\end{array}$ \\
\hline 1 &, $924^{\mathrm{a}}$ &, 855 &, 834 &, 557 \\
\hline
\end{tabular}

a. Predictors: (Constant), Birokrasi, Fasilitas, Utilitas, Fisik_Kota Ekonomi, Kualitas_Lk., Aksesbilitas, Sosial

Sumber: Hasil Penelitian, 2018

Berdasarkan Tabel 8 menunjukkan bahwa lokus Kabupaten Banyuasin dengan nilai $\mathrm{R}$ sebesar 0,924 bermakna delapan variabel independent yaitu fisik kota, kualitas lingkungan, fasilitas, utilitas, ekonomi, sosial dan birokrasi secara bersama berpengaruh terhadap penyelenggaraan sport event adalah sangat kuat. Nilai $\mathrm{R}$ Square sebesar 0,855 bermakna delapan variabel independent penelitian berpengaruh sebesar 85,5 persen dan dipengaruhi faktor lain diluar objek penelitian sebesar sisanya 14,5 persen pada lokus Kabupaten Banyuasin. 


\section{PENUTUP}

\section{Simpulan}

Berdasarkan hasil pengujian hipotesis secara parsial dari kedelapan variabel independent yang meliputi fisik kota, kualitas lingkungan, aksesbilitas, fasilitas, utilitas, ekonomi, sosial dan birokrasi diketahui bahwa pada lokus Kabupaten Banyuasin, variabel fisik kota, aksesbilitas, utilitas, ekonomi, sosial, dan birokrasi tidak memiliki pengaruh yang signifikan terhadap penyelenggaraan sport event di Provinsi Sumatera Selatan, sedangkan dua variabel lainnya yaitu kualitas lingkungan dan fasilitas memiliki pengaruh yang signifikan terhadap penyelenggaraan sport event di Provinsi Sumatera Selatan. Dari kedua variabel tersebut, variabel kualitas lingkungan memiliki tingkat pengaruh signifikan yang paling besar terhadap penyelenggaraan sport event, yang juga didukung dengan 53,03 persen tanggapan positif responden. Kemudian variabel fasilitas merupakan variabel yang juga memiliki tingkat pengaruh signifikan besar terhadap penyelenggaraan sport event, didukung dengan 57,07 persen tanggapan negatif.

\section{Saran}

1. Dari delapan variabel independent penelitian, pada lokus Kabupaten Banyuasin terdapat dua variabel yaitu kualitas lingkungan dan fasilitas yang memiliki pengaruh signifikan terhadap penylenggaraan sport event. Hal tersebut terbukti pada uji signifikansi parameter individual dengan penguatan hasil analisis deskripsi variabel, menyimpulkan bahwa kedua variabel tersebut berpengaruh signifikan dan berbanding lurus terhadap penyelenggaraan sport event di Provinsi Sumatera Selatan.

2. Pada lokus Kabupaten Banyuasin, pembenahan utama terhadap variabel kualitas lingkungan difokuskan pada indikator:
- Ketersediaan ruang terbuka hijau

- Upaya pengelolaan sampah

- Reduksi pencemaran udara

Untuk variabel fasilitas, pembenahan fokus pada indikator:

- Informasi lokasi rekreasi

- Pemberdayaan taman kota

- Keterbatasan angkutan umum

\section{DAFTAR PUSTAKA}

Cities Alliance, W. (2007). Liveable cities: the benefits of urban environmental planning: a cities Alliance study on good practices and useful tools.

Nurfaedah, Ulfi. (2015). Analisis Peran Kota Tangerang sebagai Kota Satelit Jakarta (studi kasus: transportasi komuter tangerang-jakarta) diakses melalui

http://digilib.esaunggul.ac.id/bookma rk/5292/ kota\%20 satelit.

Kaplanidou, K., \& Vogt, C. (2010). The meaning and measurement of a sport event experience among active sport tourists. Journal of Sport Management, 24(5), 544-566.

Karo Karo P. (2019). Analysis of Satellite City Readiness Effect towards Organization of Sport Events in South Sumatra Province. 1st International Conference One Belt, One Road, One Tourism (ICOBOROT 2018), Advances in Economics, Business and Management Research, 2019, volume 111, 55-65.

Kennedy, D. (2009). The spectator and the spectacle: audiences in modernity and postmodernity. Cambridge University Press.

\section{UCAPAN TERIMA KASIH}

Penulis mengucapkan terima kasih kepada Bapak Direktur Politeknik Pariwisata Medan atas bantuan dan dukungannya sehingga publikasi hasil penelitian ini dapat diterbitkan. 